\title{
MAINTAINING ORDER INFLUENCES. ANCIENT INTERPRETATIONS OF ANIMAL VIOLENCE
}

Jonathan Rosenthal

Animals in the ancient world, like individuals of lower rank, were regularly subject to violence. But some sources were more accepting of violence against animals than others. For example, Porphyry views violence against gentle sheep as unacceptable (Newmyer 87), while also viewing violence against animals that threaten to "overrun the streets" as acceptable (Newmyer 108). So, what arguments did ancient sources use to justify or condemn violence against animals?

The polarity between disorder and order occupied a prominent pedestal in the ancient understanding of the world. Order is here used to mean the systems of politics, economics, and social structure, and disorder the absence of these systems, a state like wild nature. The importance of this polarity in ancient thought is evident through examples like the development of order from Chaos in Hesiod's genealogical work, Theogony, culminating in the ordered rule of the Olympian gods. Major works of ancient philosophical thought, too, aimed at preserving order. Plato's Laws, for example, examined procedures like voting and punishment to preserve the political, economic, and social system, without which there could be disorder. Further, the social structure of the ancient world underscores the 
emphasis on order over chaos, with hierarchical strata enforced by laws, economics, and violence. Did this esteem for order, structure, and organization, then, influence how ancient sources viewed violence against animals?

The evidence that follows suggests that violence against animals in the ancient world was acceptable, though depending, at least in part, on how they were classified into the order-disorder spectrum. Animals that were seen as threatening to order - for example, in spreading diseases - were classified as more wild and disorderly. Animals employed in some manner beneficial to humans, like husbandry and arena games, though, were seen as more orderly. Viewing animals as rational did not seem to impact whether animals were seen as orderly or wild: even when viewed as rational and able to form contracts, ancient sources still suggest animals be employed in some kind of useful role to preserve order. Ultimately, if violence was necessary for the preservation of order, especially if the goal was to keep animals in a state of usefulness, it was employed. Lastly, arguments that promote kindness towards animals highlight that this kindness is, in some indirect way, to preserve order. Only in sources that don't develop a context of preserving order - for example, in non-political treatises - do authors begin to consider violence against animals as unwarranted for direct, inherent moral reasons instead of an indirect argument of keeping order in the world.

Animals, despite being nonhuman, were commonly fit into the order/disorder classification in the ancient world. Greeks gave human names to hunting animals 
and pet dogs, both of which were very much a part of social and family structure, and even buried dogs besides their masters in cemeteries (Lonsdale 149-150). In short, these animals could fit nicely into a well-ordered Greek world. But, dogs were also viewed as diseased and rabid, which aroused the Greeks' anxiety (Lonsdale 151), presumably because contagious diseases could throw whole cities into chaos. Even some pet dogs, in the right circumstances, could be feared. As Lonsdale says, "The fear that the dog will turn on his master, in essence become his successor, comes through strongly in stories like Priam's apocalyptic vision of the fall of Troy in the twenty-second book of the Iliad, where his table-dogs tear out his hair and rip away his genitals" (152). This fear seems to come in part from a threat to order, the overturning of the master-animal relationship. Porphyry cites another argument of a threat posed by animals: in their natural tendency to over-breed, animals could "overrun the streets" if left unchecked (Newmyer 108). Outside homes and towns, there are assertions that hunting is necessary because it provides humans "expressions of triumph at the removal of beasts intent upon obliterating the human race." (Newmyer 87 emphasis added). So, what could be done about these threats to order posed by animals, both tame and wild ones?

Aristotle claims that human beings wage a "just war against wild nature." (Politics 1256b23-26 via Newmyer 87), evidencing a longstanding tradition of using violence to preserve order against the wild and chaotic. But, instead of just obliterating threatening animals, it seems it was most expedient to organize a system in which animals were of some service to humans. As an analogy, Zeus, in 
Hesiod's Theogony, originally locks enemies like the Hundred-Handed ones up. But when Zeus is warring with the Titans, he unleashes them as allies. For order they are originally banished, but then Zeus deems harnessing their indispensable powers more worthwhile. Similarly, animals were harnessed for economic (e.g. husbandry, cattle as a currency [Lonsdale 147-148]), religious (e.g. the cult of Asklepios in which dogs were integral in therapy, licking invalids back to health [Lonsdale 150]), and protective functions (e.g. dogs warding off burglars and assisting on hunts [Lonsdale 149]). Animals could also serve as entertainment by pitting their chaotic forces against each other in popular cock-fights (Newmyer 155), or in arena games. To ensure animals did not stray from these orderly roles, and especially to train them, violence in the form of whips (Newmyer 65), branding irons, and chains were often used (Newmyer 108). All of this suggests a view that animal nature is wild and man has a role in taming it to preserve order.

Despite the wild nature often attributed to animals, some sources, like Aristotle (History of Animals 615b23-24), Aelian (Nature of Animals III 23), and Plutarch (On the Cleverness of Animals 962), saw evidence for a degree of reason in animals, like birds, who follow their leaders (all via Newmyer 85). Does whether animals are viewed as rational or irrational, then, influence where they fit on the order/wild spectrum? For example, one might expect rational animals to be more suited to order. But ultimately, this appears to not be the case. What matters is whether the animals were threatening to whatever order existed, not whether the animal was rational. In fact, rational animals could even be seen as more 
threatening. Thus, Democritus argues that animals may act contrary to order in a manner that suggests an intention to do so. Consequently, humans who commit violence against such animals are justified in doing so (Newmyer 83). Violence could also be used to preserve the guardianship humans offer in return for animals' services and products, much like a covenant or contract between rational beings, as suggested by Lucretius (Newmyer 29). This is similar to how a slave owner might use violence to keep order among his slaves, for as Plutarch says, "Perfect reason, after all, is scarcely to be isolated even in human beings" and in them it is the result of much care and training (Newmyer 17). So, even when considered rational, animals could still be treated with violence to prevent any discord or chaos, which suggests that concerns about maintaining order in the world largely determined attitudes about violence toward animals.

Violence, however, only helps in certain circumstances to preserve order. Specifically, when animals are disorderly, violence is acceptable to preserve order. But, as Newmyer summarizes Pythagoras's view: how can sheep be subject to violence when they are "a gentle flock born to dwell among humans, bearing their nectar in full udders, creatures that provide us their wool for clothing" (87). Ovid, too, denies that humans can justly hurt tame animals that are "our partners in labor" (Newmyer 99). Because violence against these animals does not help order in any way, it is unnecessary and even damaging to order because it hurts animals that are our partners, that already help us. Thus, these sources use the same 
argument, that is, preserving order, to identify circumstances in which violence was unwarranted.

The reason violence against tame animals is unacceptable, to these sources, though, is not respect for animals so much as a belief that unnecessary human violence towards animals promotes violence among humans, and this ultimately threatens order. Pythagoras, for example, argues that "humans are enjoined to refrain from cruelty to animals because kindness to them promotes kindness to human beings" (Newmyer 114). Likewise, that cruelty towards animals promotes cruelty to human beings, particularly by desensitizing the perpetrator, is explicitly expressed by Plutarch in his reference to the escalating cruelty of the Athenian Tyrants (Newmyer 88). Plutarch even goes so far as to portray cruelty against ordered and non-threatening animals as wild and chaotic itself (Newmyer 108). These arguments are not about the animals' suffering, but instead the effects of increasing violence in human social relations. This further supports the claim that considerations about order and disorder are central in how sources view violence against animals.

The selection of works available, however, is a limiting factor in this analysis. Many of the extant works from the ancient world are concerned with politics, and, in general, anthropocentric. This can bias our interpretation. Aristotle, for example, denies intellectual and moral capacities to animals in his more anthropocentric works, such as Politics and Nicomachean Ethics, than he attributes them in his 
biological works (Newmyer 8). And, the focus of a piece, and how concerned it is with order, could influence the author's interpretation of violence against animals. So, for example, Plutarch, in his ethical work On the Eating of Flesh, began to imply that the wanton treatment of other species is abominable (Newmyer 78). This implies that threatening animals still needed to be handled with violence, but using violence to tame useful animals, and even using animals in general, was morally unsound. As Newmyer says, "Plutarch maintains that non-human animals love their offspring as tenderly as do human parents," and so by treating them as trained, furry tools, humans violate animals' own sense of justice (16). Overall, without a context of preserving order, sources begin to interpret violence against animals differently. When the context no longer considers ultimately how order can be preserved, sources begin implicitly to describe animals as beings endowed with a sense of justice and thus deserving of it. This highlights an exception that emphasizes the rule of preserving order's influence on ancient interpretations of violence against animals.

In sum, then, the goal of preserving order guided the interpretation of violence against animals in the ancient world. As a means of taming the "wild nature" (Aristotle via Newmyer 87) of animals to secure the political, economic, or social systems of the time - in other words, to secure order - violence was acceptable. In describing the threats posed by animals, sources often specifically recommend violence as a means of preventing discord, like hunting to curtail animal populations "intent on destroying the human race" (Newmyer 87). What was most 
expedient, though, was the use of animals to contribute to order, especially the economic and social systems in roles like husbandry and religious functions. Violence, then, was used to train and keep animals in these orderly roles. Even when sources considered animals rational and exchanging these services for guardianship, as in a contract, they still justified violence against animals to secure their functions in the economic and social system. Further, describing circumstances where violence against animals is unwarranted, ancient sources offer the argument that violence against already tame animals disrupted order in some way: either by being unnecessary damage to already helpful animals or by leading humans to become more apt to commit violence among other humans. Only in works that have less of an emphasis on order and disorder, for example Plutarch's On the Eating of Flesh, do interpretations of violence against animals depart from the otherwise consistent preservation-of-order arguments. All of this points to the preservation of order as an important influence on the way ancient sources both justified and critiqued violence against animals.

WORKS CITED

LONSDALE, STEVEN H., Attitudes Towards Animals in Ancient Greece, in Greece and

Rome, Vol. 26/ 02 (1979) 146ff. (www.journals.cambridge.org)

NEWMYER, STEPHEN THOMAS, Animals in Greek and Roman Thought: A Sourcebook. 


\section{dA derecho ANIMAL}

la web center de los animales con derecho

(London Routledge, 2011). Reviewed by Susan A. Curry, in Bryn Mawr Classical Review

2011.07.38 (http://bmcr.brynmawr.edu/2011/2011-07-38.html) 